\title{
Status of Peste Des Petits Ruminants in Small Ruminants of Semi Arid Regions of Rajasthan
}

\author{
Mahender Milind ${ }^{1}$, Bincy Joseph ${ }^{1 *}$, D.K. Sharma ${ }^{1}$, Abhishek Gaurav ${ }^{1}$, \\ M.C. Sharma ${ }^{1}$ and Chandan Prakash ${ }^{2}$ \\ ${ }^{1}$ Department of Veterinary Microbiology, College of Veterinary and Animal science, Navania, \\ Udaipur 313601, India \\ ${ }^{2}$ Animal Health Division, CSWRI, Avikanagar, Malpura, Tonk 304501, India
}

*Corresponding author

\section{Keywords}

Seroprevalence, PPR, Sheep and Goat, Sandwich ELISA, Competitive ELISA

Article Info

Accepted:

12 November 2018

Available Online:

10 December 2018

\section{A B S T R A C T}

A prevalence study of PPR among small ruminants was conducted in five districts (Udaipur, Dungarpur, Rajsamand, Chittorgarh and Banswara) of southern Rajasthan including both vaccinated and unvaccinated flocks of sheep and goats. The overall seroprevalence of PPR virus antibodies in vaccinated small ruminants is $42 \%$ with highest prevalence in Chittorgarh (54.95\%) and lowest in Banswara (12\%). In unvaccinated group, the overall seroprevalence is $42.18 \%$ with highest prevalence in Banswara $(66.07 \%)$ and lowest prevalence in Udaipur district (19.04\%). In the case of groups with unknown vaccination status also the highest prevalence was in Banswara district $(79.16 \%)$ and the lowest prevalence in Dungarpur district (18.18\%). The proportion of seropositive animals significantly differs between districts, species and age. There was no statistical difference in the seroprevalence recorded in male (33.96\%) compared to that in female (43.79\%). The PPR seroprevalence recorded in goat (53.86\%) is significantly higher than sheep (20.31\%). Among different age groups, animals more than 2 year old showed more seroprevalence (57.39\%) compared to 1-2 year age group (44.17\%) and less than 1 year old $(39.53 \%)$. Only $16.5 \%$ total population of small ruminants appeared to have protective PPRV specific antibody response i.e. percent inhibition (PI) > 76\%). Out of a total of 160 suspected sample (oral and nasal swab) examined with sandwich ELISA, 4 (2.5\%) samples were positive for PPR viral antigen. This study showed varying antibody levels in the districts screened reflecting the infection and vaccination profiles of the herds.

\section{Introduction}

Peste des petits ruminants (PPR), also known as goat plague, is a viral disease of goats and sheep characterized by fever, sores in mouth, diarrhea, pneumonia and sometimes death. PPR virus belongs to genus Morbillivirus in the family Paramyxoviridae. PPR was first reported in Cote d'Ivoire in West Africa (Gargadennec and Lalanne, 1942), and later in other parts of the world, namely sub-Saharan Africa, the Arabian Peninsula, the Middle East and the Indian subcontinent (Shaila et al., 1996) In India, PPR was first recorded in 1987 
from Arasur village, in the Villupuram district of Tamil Nadu (Shaila et al., 1989), and it continued to be present in the southern Peninsula until 1994. Later, a number of PPR outbreaks were reported from the northern states of India (Kerur et al., 2008), with a solitary report in Indian buffalo in a southern state (Govindarajan et al., 1997).

PPR affects sheep and goats primarily, and occasionally infects wildlife also. PPRV was classified into 4 lineages I - IV based on the F gene sequencing (Dhar et al., 2002) (Shaila et al., 1996) of which, only lineage IV viruses have been reported in India (Balamurugan et al., 2011; Dhar et al., 2002; Shaila et al., 1996). The mortality usually ranges from $50 \%$ to $90 \%$, although it sometimes can be zero, and morbidity varies from $10 \%$ to $100 \%$, or sometimes lower than $10 \%$, depending on circumstances. It is a major constraint on small ruminant production (Saravanan et al., 2006), causing great economic losses because of morbidity, mortality, and losses of productivity due to trade restrictions. Economic losses due to PPR have been estimated to be 1,800 million INR annually (Yadav et al., 2009). The seroprevalence study will be helpful in knowing prevalence status of disease which in turn helps in implementation of disease control strategies and vaccination programme. Efficient and sensitive diagnostic tests are a great help in rapidly providing evidence that PPRV is circulating in a free-ranging population. A monoclonal antibody (MAb)-based competitive enzyme-linked immunosorbent assay (c-ELISA) and a sandwich ELISA, for detection of PPRV antibody and antigen respectively, were developed at the Indian Veterinary Research Institute (IVRI), Mukteswar (Singh et al., 2004b) (Singh et al., 2004). These are the tests currently employed for serosurveillance and seromonitoring of the clinical prevalence of PPR throughout India. The eradication of PPR through PPR control programme can be achieved only by identification of areas of infection by comprehensive surveillance and then implementing intensive vaccination campaigns in those areas.

\section{Materials and Methods}

\section{Study area and population}

The study area includes five districts (Udaipur, Banswara, Chittorgarh, Dungarpur and Rajsamand) of southern Rajasthan of India. These areas are epidemiologically cross linked through seasonal admixture of the herds during grazing and marketing. The study was carried out in 18 villages, selected from these five districts (Table 1). The study population was small ruminants that are apparently healthy as well as those showing clinical signs that resemble PPR signs. Villages and individual animals were selected based on random sampling.

\section{Collection of samples and preservation Serum samples}

A total of 633 serum samples were collected from sheep $(n=128)$ and goats $(n=505)$ in the study districts. The aim was to determine the level of antibody in the serum/herd immunity in vaccinated areas as well as the seroprevalence of infection in non-vaccinated areas. Supplementary potential risk factors such as animal's age, sex, health status etc were recorded during blood sampling.

\section{Clinical samples}

A total of 160 samples, comprising nasal and oral swabs were collected from the suspected animals for the presence of PPR viral antigen. During the entire study (2016-17) we have not come across with any outbreaks of PPR or any clinical cases which showing typical clinical signs of PPR. The swab samples were 
collected from animals having respiratory infections using sterile swabs which were placed in a viral transport media (VTM) containing PBS, antibiotics and antifungal agents.

\section{Antibody detection by competitive ELISA}

PPR competitive ELISA (procured from IVRI, Mukteswar, India) was used for detection of PPRV antibodies as described earlier (Singh $e t$ al., 2004b). Samples with percentage inhibition (PI) of $>40 \%$ were considered positive for the presence of PPRV antibodies.

\section{Antigen detection by sandwich ELISA and virus isolation}

PPR sandwich ELISA (procured from IVRI, Mukteswar, India) was used for the detection of PPR antigen as described earlier (Singh et al., 2004). Further, for isolation of virus, the $25 \mathrm{~cm}^{2}$ culture flask containing Vero cell monolayer with $80 \%$ confluency, was infected with $1 \mathrm{ml}$ of processed tissue filtrate in DMEM media by adsorption method with change the media every alternate day and maintained for 6-8 days. Then subculture of the cells (periodically up to 10 passage level) after every $8^{\text {th }}$ day was carried out and maintained the cells till the observation of specific PPR V cytopathic effect.

\section{Statistical analysis}

Proportions were calculated for seroprevalence vis-a-vis fixed factors that included animal species, sex and age, and districts. Univariable analysis for the proportions was carried out using Chi-square analysis in SPSS version 22 to assess association with the districts, species, age and sex. A $p$ value $<0.05$ indicates a significant level. Apparent prevalence and true prevalence also calculated using the following formula (Thrusfield, 2007). (i) Apparent prevalence $=$ number of positive animals/number of tested animals. (ii) True prevalence $=$ [apparent prevalence + (specificity -1$)] /[($ sensitivity + specificity) -1$]$. True prevalence rate was calculated based on the sensitivity and specificity of the c-ELISA employed in the study, which is having high relative specificity $(98.4 \%)$ and sensitivity (92.4 \%) when compared with virus neutralization assay (Singh et al., 2004a).

\section{Results and Discussion}

\section{Detection of PPR V antibody}

The percent color inhibition using cELISA provided an indirect measure of antibody levels in the test serum samples (Figure 1). Among the samples considered negative for PPRV (PI $<40 \%)$ the greatest number of samples have a PI between $-10 \%$ to $-15 \%$. Alternatively, among the samples considered positive for PPRV, PI $\geq 40 \%$ a peak frequency of distribution between $85 \%$ and $90 \%$ was observed. The PI values (ranges from -15 to 100) obtained in competitive ELISA from tested serum samples were classified as five categories. Most of the serum samples $(\mathrm{n}=$ 228) showed PI values $<35$ reactivity in ELISA representing the negative. There were 37 samples falling in the range between 35 and 40 PI (suspected), 107 samples in the range of 40 and $50 \mathrm{PI}$ (positive), 156 samples in the range between 60 and 80 PI (Weak positive) and 105 samples in the range between 80 and $100 \mathrm{PI}$ (Strong positive).

The percent positivity of PPRV antibodies in small ruminants with apparent and true prevalence are presented in table 2. Analysis of 633 serum samples from small ruminants (sheep, $\mathrm{n}=128$; Goat, $\mathrm{n}=505$ ) indicated overall prevalence of PPR virus antibodies in vaccinated small ruminants is $42 \%$ with highest prevalence in Chittorgarh $(54.95 \%)$ and lowest in Banswara (12\%) (Table 3). 
In unvaccinated group, the overall seroprevalence is $42.18 \%$ with highest prevalence in Banswara (66.07\%) and lowest prevalence in Udaipur district (19.04\%) with a $\mathrm{p}$ value of 0.000 . In the case of groups with unknown vaccination status also the highest prevalence was in Banswara district (79.16\%) and the lowest prevalence in Dungarpur district (18.18\%). The difference was statistically significant with a $\mathrm{p}$ value of 0.001 . There was no statistical difference in the seroprevalence recorded in male (33.96\%) compared to that in female $(43.79 \%)$ $(\mathrm{p}=0.166)$ and seroprevalence recorded in goat $(53.86 \%)$ is significantly higher than sheep $(20.31 \%)(p=0.000)$ (Table 4$)$.

\section{Detection of antigen by sandwich ELISA}

Out of a total of 160 suspected sample (Oral and nasal swab) examined with sandwich ELISA, only $4(2.5 \%)$ samples were positive for PPR viral antigen. None of the samples attempted for virus isolation in vero cells revealed specific PPRV CPE even after many passages.

Table.1 Sheep and goat population of study area, number of samples collected and villages selected for sample collection in the study area

\begin{tabular}{|c|c|c|c|c|}
\hline Districts & Sheep & Goat & Number of sample & Village selected \\
\hline Udaipur & 140626 & 1106814 & 97 & $\begin{array}{l}\text { Uddaikhera, Rundeda, Ranthed, Kheroda, } \\
\text { Sakeriyakheri }\end{array}$ \\
\hline Dungarpur & 62652 & 416729 & 158 & Aaspur, Saagwara, Bichiwara \\
\hline Banswara & 7207 & 504758 & 105 & $\begin{array}{l}\text { Bagidora, Peeplikhoot, Ghatol, Garhi, } \\
\text { Banswara }\end{array}$ \\
\hline Chittorgarh & 43941 & 474799 & 129 & Bojunda Goat farm at Chitttorgarh \\
\hline Rajsamand & 100488 & 536901 & 144 & Nathdwara, Rail magra, Devgarh, Kelwa \\
\hline
\end{tabular}

Table.2 Details of serum samples screened for peste des petits ruminants virus antibodies in small ruminants

\begin{tabular}{|l|r|r|r|r|}
\hline \multicolumn{1}{|c|}{ Districts } & $\begin{array}{c}\text { Total number of } \\
\text { samples } \\
\text { screened }\end{array}$ & \multicolumn{1}{|c|}{$\begin{array}{c}\text { Positive in } \\
\text { Competitive } \\
\text { ELISA }\end{array}$} & $\begin{array}{c}\text { Apparent } \\
\text { prevalence (\%) }\end{array}$ & $\begin{array}{c}\text { True prevalence } \\
(\%)\end{array}$ \\
\hline Udaipur & 122 & 36 & 29.5 & 66.85 \\
\hline Dungarpur & 186 & 56 & 30.1 & 67.17 \\
\hline Rajsamand & 169 & 65 & 38.36 & 71.52 \\
\hline Banswara & 130 & 62 & 47.69 & 76.44 \\
\hline Chittorgargh & 154 & 74 & 28.05 & 66.09 \\
\hline
\end{tabular}

Table.3 Overall seroprevalence of PPR among various vaccination status of small ruminants of five districts

\begin{tabular}{|c|c|c|c|c|c|c|c|c|c|c|c|c|c|c|c|}
\hline \multirow[t]{2}{*}{ Districts } & \multicolumn{5}{|c|}{ Vaccinated } & \multicolumn{5}{|c|}{ Unvaccinated } & \multicolumn{5}{|c|}{ Unknown Status } \\
\hline & $\mathbf{N}$ & pos & $\%$ & $\chi^{2}$ & $P$ value & $\mathbf{N}$ & pos & $\%$ & $x^{2}$ & P value & $\mathbf{N}$ & pos & $\%$ & $x^{2}$ & P value \\
\hline Udaipur & 62 & 21 & 33.87 & 18.78 & 0.001 & 21 & 4 & 19.04 & 23.75 & 0.000 & 14 & 6 & 42.85 & 17.41 & 0.001 \\
\hline Dungarpur & 53 & 22 & 41.5 & & & 83 & 26 & 31.3 & & & 22 & 4 & 18.18 & & \\
\hline Rajsamand & 49 & 19 & 38.77 & & & 78 & 36 & 46.15 & & & 17 & 9 & 52.94 & & \\
\hline Banswara & 25 & 3 & 12 & & & 56 & 37 & 66.07 & & & 24 & 19 & 79.16 & & \\
\hline Chittorgarh & 111 & 61 & 54.95 & & & 18 & 5 & 27.77 & & & 0 & 0 & 0 & & \\
\hline Overall & 300 & 126 & 42 & & & 256 & 108 & 42.18 & & & 77 & 38 & 49.35 & & \\
\hline
\end{tabular}


Table.4 Association of assumed exposure variables with seropositivity of PPR

\begin{tabular}{|c|c|c|c|c|c|c|}
\hline \multirow[t]{2}{*}{ Variables } & \multirow[t]{2}{*}{ Categoris/levels } & \multirow[t]{2}{*}{$\mathrm{N}$} & \multicolumn{2}{|c|}{ Seropositives } & \multirow[t]{2}{*}{$x^{2}$} & \multirow[t]{2}{*}{$P$ value } \\
\hline & & & $\mathbf{N}$ & $\%$ & & \\
\hline \multirow[t]{5}{*}{ Districts } & Udaipur & 97 & 31 & 31.95 & \multirow[t]{5}{*}{22.526} & \multirow[t]{5}{*}{0.000} \\
\hline & Dungarpur & 158 & 52 & 32.91 & & \\
\hline & Rajsamand & 144 & 59 & 40.97 & & \\
\hline & Banswara & 105 & 59 & 56.19 & & \\
\hline & Chittorgargh & 129 & 66 & 51.16 & & \\
\hline \multirow[t]{2}{*}{ Species } & Sheep & 128 & 26 & 20.31 & \multirow[t]{2}{*}{33.66} & \multirow[t]{2}{*}{0.000} \\
\hline & Goat & 505 & 24 & 53.86 & & \\
\hline \multirow[t]{3}{*}{ Age } & Less than 1 year & 86 & 34 & 39.53 & \multirow[t]{3}{*}{10.46} & \multirow[t]{3}{*}{0.005} \\
\hline & $1-2$ year & 378 & 167 & 44.17 & & \\
\hline & More than 2 year & 169 & 97 & 57.39 & & \\
\hline Sex & Male & 53 & 18 & 33.96 & 1.915 & 0.166 \\
\hline
\end{tabular}

Figure.1 Distribution of colour inhibition for small ruminants along with cut off value for detection of positive (PI > 40\%) and viral challenge protective (PI > 75\%) antibody titer in the test sera using cELISA

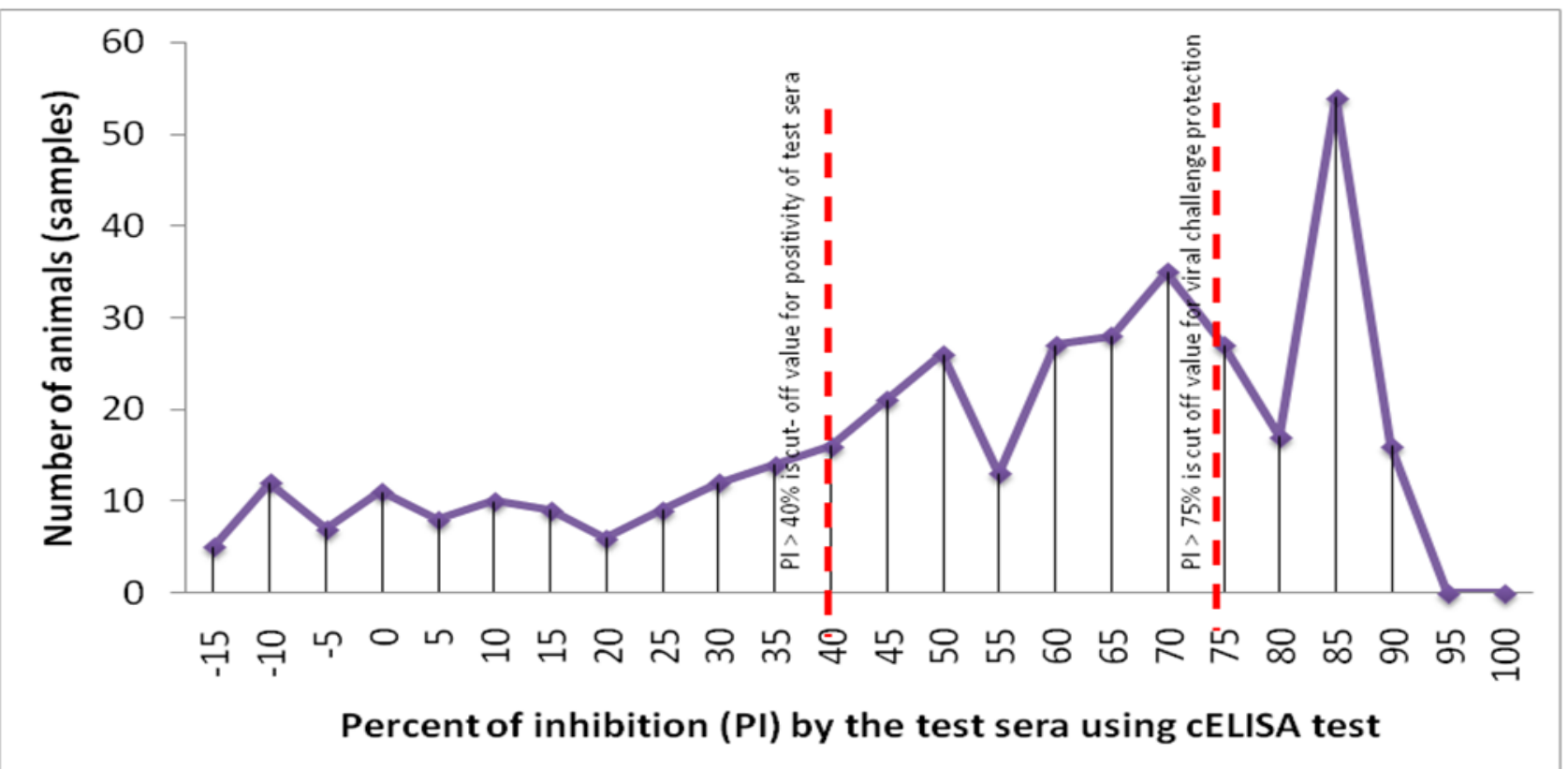

Detection and quantitation of PPR V antibodies in small ruminants in different geographical area of the country with varying agro climatic conditions may be helpful in knowing the prevalence status and implementation of control strategies or vaccination programme. This is the first report of prevalence of PPR in southern Rajasthan even though this region is well known for sheep and goat rearing. The present investigation has provided baseline information about the prevalence of PPR antibodies in sheep and goats of different sex, age and districts of southern Rajasthan during the period of 2016-17.

Seroprevalence study was conducted in 18 villages of five districts southern Rajasthan 
(Udaipur, Rajsamand, Dungarpur, Banswara and Chittorgarh). Both vaccinated and unvaccinated flocks were investigated for the presence of PPR antibody. This study found that $42 \%$ of the vaccinated small ruminant population were protected against PPRV, this is quite low compared to the minimum of 75$80 \%$ herd immunity required to control rinderpest (Rossiter and James, 1989). This low level of PPRV sero-positivity found in this study was unexpected since the PPR vaccine has been reported to confer protection for up to three years (Singh et al., 2004)(Diallo et al., 2007). However, the immunogenicity of PPR vaccine has been reported to vary. Arguably, the vaccine used in these areas may not be appropriate or cold chain for vaccines is not maintained properly, and so there is need to give a booster dose to induce a higher immunologic response.

Among the unvaccinated small ruminants, 42.18\% had antibodies to PPRV which means that those animals could have been exposed to the field virus or got in contact with those that shed the vaccine virus. The sero-positive unvaccinated animals as detected by this study could perpetuate the dissemination of the virus among susceptible sheep and goats (Ezeibe et al., 2008) Therefore, surveillance activities are needed to determine the importance of these shedders to PPRV prevention and control efforts (Anderson and McKay, 1994). The level of sero-positivity among vaccinated sheep and goats and those with unknown vaccination history were similar. (Balamurugan et al., 2014) attributed greater PPR positivity in clinical samples from goats to the fact most of the suspected samples were from regions, which had larger goat population. Similarly Soundararajan et al., (2006) reported a higher mortality rate among infected goats than sheep in a large organized farm, which too has larger goat population. In the present study also $75 \%$ of the serum samples from goat population and the area under study also have larger goat population than sheep. So the higher seropositivity in goat may be attributed to the sample size. But in a recent study from Tanzania, significantly more seropositive individuals were found among goats than among sheep (49.5 vs. $39.8 \% ; \mathrm{p}=0.02$ ), with an overall seroprevalence of $45.8 \%$ (Swai $e t$ al., 2009). They have suggested that these variations in seroprevalence could be due to differences in sample size, age, prevailing management practices, humidity or season, etc. (Singh et al., 2004).

Among different age groups, animals more than 2 year old showed more seroprevalence (57.39\%) compared to $1-2$ year age group $(44.17 \%)$ and less than 1 year old (39.53\%). The findings of this study also suggest that animals that were more than 2 years old had a better sero-positivity to PPR than any other age groups. Our data suggested that animals younger than 1 year had lower chances of being sero-positive to PPR. These findings are in agreement with previous reports by(Abubakar et al., 2009)(Özkul et al., 2002) (Singh et al., 2004a) who found that younger animals were more susceptible to PPRV. It has been documented that sheep and goats exposed to PPRV at a very young age may carry antibodies for 1-2 year following exposure (Dhar et al., 2002; Özkul et al., 2002; Singh et al., 2004a). The present survey provides only preliminary information on PPR sero- epidemiology, because the samples analysed may not be a true representation of the target population. However, the information will be very useful in the formulation of effective disease management strategies and in the implementation of a PPR vaccination programme under National control programme on PPR (NCP-PPR) in southern Rajasthan. The findings of PPRV antibodies in unvaccinated animals in the different districts suggested that disease could be spread by movement of animals and the 
serological status suggest different level of vaccination coverage in the districts which has implication on the control of the disease. More systematic, intensive and comprehensive active serological surveillance programme in small ruminants along with measurement of clinical prevalence in the enzootic areas of southern Rajasthan and then implementing intensive vaccination campaigns in these areas, must be undertaken in order to develop effective control measures for PPR.

Although there are few reports about the seroprevalence of PPR antibodies in different areas of the state, the clinical findings of this study confirmed the circulation of PPR virus among populations of sheep and goats in the study areas and prevalence in actual outbreaks situation, which should be kept in mind while deciding the vaccination strategy for the control of the disease. This study showed varying antibody levels in the affected districts reflecting the infection and vaccination profiles of the herds. There was serological evidence of seroconversion to the vaccine and seroprevalence to the circulating virus suggesting the level of vaccine coverage which is not enough to achieve herd immunity should the disease strike again in the population.

In conclusion, the present survey was the first study of seroprevalence of PPR in southern Rajasthan and it provides only preliminary information on PPR sero-epidemiology, because the samples analysed may not be a true representation of the target population. However, the information will be very useful in the formulation of effective disease management strategies and in the implementation of a PPR vaccination programme under NCP-PPR in southern Rajasthan of India.

Acknowledgement
The authors are thankful to Vice Chancellor, RAJUVAS, Bikaner and Dean, CVAS, Navania for the providing all necessary facilities for carrying out this research work.

\section{References}

Abubakar, M., Jamal, S.M., Arshed, M.J., Hussain, M., Ali, Q. (2009). Peste des petits ruminants virus (PPRV) infection; Its association with species, seasonal variations and geography. Trop. Anim. Health Prod. 41:1197-1202.

Anderson, J., McKay, J.A. (1994). The detection of antibodies against peste des petits ruminants virus in cattle, sheep and goats and the possible implications to rinderpest control programmes. Epidemiol. Infect. 112:225-31.

Balamurugan, V., Hemadri, D., Gajendragad, M.R., Singh, R.K., Rahman, H. (2014). Diagnosis and control of peste des petits ruminants: a comprehensive review. Virusdisease, 25: 39-56.

Balamurugan, V., Saravanan, P., Sen, A., Rajak, K. K., Bhanuprakash, V., Krishnamoorthy, P., Singh, R.K. (2011). Sero-epidemiological study of peste des petits ruminants in sheep and goats in India between 2003 and 2009. Rev. sci. tech. Off. int. Epiz., 30: 889-896.

Dhar, P., Sreenivasa, B.P., Barrett, T., Corteyn, M., Singh, R.P., Bandyopadhyay, S.K. (2002). Recent epidemiology of peste des petits ruminants virus (PPRV). Vet. Microbiol., 88;153-159.

Ezeibe, M.C.O., Okoroafor, O.N., Ngene, A.A., Eze, J.I., Eze, I.C., Ugonabo, J.A.C. (2008). Persistent detection of peste de petits ruminants antigen in the faeces of recovered goats. Trop. Anim. Health Prod., 40: 517-519.

Gargadennec, L., Lalanne, A. (1942). La peste des petits ruminants Bulletin des Services Zoo Techniques et des Epizzoties de 1'Afrique Occidentale Francaise, 5 (1942), pp. 16-21

Govindarajan, R., Koteeswaran, A., 
Venugopalan, A.T., Shyam, G., Shaouna, S., Shaila, M. S., Ramachandran, S. (1997). Isolation of pestes des petits ruminants virus from an outbreak in Indian buffalo (Bubalus bubalis). Vet. Rec. 141: 573-574.

Kerur, N., Jhala, M.K., Joshi, C.G. (2008). Genetic characterization of Indian peste des petits ruminants virus (PPRV) by sequencing and phylogenetic analysis of fusion protein and nucleoprotein gene segments. Res. Vet. Sci., 85, 176-183.

Özkul, A., Akca, Y., Alkan, F., Barrett, T., Karaoglu, T., Dagalp, S.B., Anderson, J., Yesilbag, K., Cokcaliskan, C., Gencay, A., Burgu, I. (2002). Prevalence, Distribution, and Host Range of Peste des petits ruminants virus, Turkey. Emerg. Infect. Dis., 8: 708-712.

Rossiter, P. B., James, A. D. (1989). An epidemiological model of PPR. Simulations of the behavior of PPR virus in populations. Tropical Animal Health Prod., 21: 69-84.

Saravanan, P., Balamurugan, V., Sen, A., Sahay, B., Singh, R.K. (2006). Development of Dot-ELISA for Diagnosis of Peste des petits ruminants (PPR) in Small Ruminants. J. Appl. Anim. Res., 30: 121-124.

Shaila, M.S., Purushothaman, V., Bhavasar, D., Venugopal, K., Venkatesan, R.A. (1989). Peste des petits ruminants of sheep in India. Vet. Rec., 125: 602.

Shaila, M.S., Shamaki, D., Forsyth, M.A., Diallo, A., Goatley, L., Kitching, R.P., Barrett, T. (1996). Geographic distribution and epidemiology of peste des petits ruminants virus. Virus Res., 43: 149-53.

Singh, R.P., Sreenivasa, B.P., Dhar, P.,
Bandyopadhyay, S.K. (2004). A sandwich-ELISA for the diagnosis of Peste des petits ruminants (PPR) infection in small ruminants using antinucleocapsid protein monoclonal antibody. Arch. Virol. 149: 2155-2170.

Singh, R.P., Saravanan, P., Sreenivasa, B.P., Singh, R.K., Bandyopadhyay, S.K. (2004a). Prevalence and distribution of peste des petits ruminants virus infection in small ruminants in India. Rev. Sci. Tech. 23: 807-819.

Singh, R.P., Sreenivasa, B.P., Dhar, P., Shah, L.C., Bandyopadhyay, S.K. (2004b). Development of a monoclonal antibody based competitive-ELISA for detection and titration of antibodies to peste des petits ruminants (PPR) virus. Vet. Microbiol., 98: 3-15.

Soundararajan, C., Sivakumar, T., Ramesh, S., Muthukrishnan, S., Palanidorai, R.(2006). Peste des petits ruminants among sheep and goats in an organized farm in Tamil Nadu. Indian vet. J., 83(10): 1045-1047.

Swai, E. S., Kapaga, A., Kivaria, F., Tinuga, D., Joshua, G., Sanka, P. (2009). Prevalence and distribution of peste des petits ruminants virus antibodies in various districts of Tanzania. Vet. Res. Commun., 33: 927-936.

Thrusfield, M. V. (2007). Veterinary epidemiology. Blackwell Science.

Yadav, V., Balamurugan, V., Bhanuprakash, V., Sen, A., Bhanot, V., Venkatesan, G., Riyesh, T., Singh, R.K. (2009). Expression of Peste des petits ruminants virus nucleocapsid protein in the prokaryotic system and its potential use as a diagnostic antigen or immunogen. J. Virol. Methods., 162(1-2): 56-63.

\section{How to cite this article:}

Mahender Milind, Bincy Joseph, D.K. Sharma, Abhishek Gaurav, M.C. Sharma, Chandan Prakash. 2018. Status of Peste des petits Ruminants in Small Ruminants of Semi Arid Regions of Rajasthan. Int.J.Curr.Microbiol.App.Sci. 7(12): 1217-1224. doi: https://doi.org/10.20546/ijcmas.2018.712.152 